\title{
Eksistensialisme dalam Pendidikan
}

\author{
Lailatu Rohmah \\ Fakultas Ilmu Tarbiyah dan Keguruan \\ UIN Sunan Kalijaga, Indonesia \\ lailatu84@gmail.com
}

\begin{abstract}
The philosophy of existentialism, is a philosophy with the main thought being "existence precedes the essence" that man exists first, then in life he gives meaning or essence to his life by focusing on individual experiences. Existentialism gives individuals a way of thinking about life, what it means to me, what is true for me. Existentialist epistemology assumes that individuals are responsible for their own knowledge. The main source of knowledge is personal experience. An idealist teacher according to existentialists is a teacher who provides an open dialogue space for students to find their meaning. Students get broad opportunities to learn something that interests them, so they can find their identity. Appropriate learning methods according to existentialists are dialogue, role playing, and other methods that give freedom for students to explore meaning in themselves. Because the main task of education is to stimulate every human being to be aware of the responsibility to create meaning and definition of himself.
\end{abstract}

Keywords: existentialism philosophy, ideal teacher, freedom of expression

\begin{abstract}
Abstrak
Filsafat eksistensialisme, yakni filsafat dengan pemikiran utamanya adalah "eksistensi mendahului esensi" bahwa manusia eksis/ada terlebih dahulu, kemudian dalam kehidupan dia memberi makna/esensi atas kehidupannya dengan fokus pada pengalaman individual. Eksistensialisme memberi individu suatu jalan berpikir mengenai kehidupan, apa maknanya bagi saya, apa yang benar untuk saya. Epistomologi eksistensialis menganggap bahwa individu bertanggung jawab akan pengetahuannya sendiri. Sumber pengetahuan yang utama adalah pengalaman pribadi. Guru yang ideal menurut eksistensialis adalah guru yang memberikan kebebasan ruang dialog bagi siswa untuk menemukan makna dirinya. Siswa mendapat kesempatan yang luas untuk mempelajari sesuatu yang menjadi minatnya, sehingga bisa menemukan jatidirinya. Metode pembelajaran yang tepat menurut eksistensialis adalah dialog, main peran, dan metode lain yang memberi kebebasan bagi siswa untuk bereksplorasi memaknai dirinya. Karena tugas pendidikan yang utama adalah merangsang setiap manusia agar tersadar bahwa dia sendirilah yang memiliki tanggung jawab untuk menciptakan makna dan definisi dirinya sendiri.
\end{abstract}

Kata Kunci: filsafat eksistensialisme, guru ideal, kebebasan berekspresi 


\section{A. Pendahuluan}

Masalah pendidikan adalah masalah yang menyangkut seluruh aspek hidup dan kehidupan manusia. Bahkan pendidikan juga menghadapi persoalan- persoalan yang tidak mungkin dijawab dengan menggunakan analisa ilmiah semata- mata, tetapi memerlukan analisa dan pemikiran yang mendalam, yaitu analisa filsafat.

Hubungan antara filsafat dengan teori pendidikan antara lain tergambar dalam: Pertama, Filsafat, mengandung arti analisa yang merupakan salah satu metode yang digunakan para pakar pendidikan untuk memecahkan permasalahan pendidikan dan menyusun konsep-konsep (teori-teori) pendidikan; Kedua, Filsafat berfungsi memberikan arah (pedoman) agar teori pendidikan yang telah dikembangkan berdasarkan dan sejalan dengan pandangan dan aliran filsafat tertentu yang memiliki relevansi dengan kehidupan nyata; Ketiga, termasuk juga filsafat Pendidikan yang mempunyai fungsi dalam memberikan petunjuk dan arah pengembangan teori-teori (konsep-konsep) pendidikan menjadi ilmu pendidikan atau pedagogik.

Hubungan antara pendidikan dan filsafat pendidikan akan semakin penting, karena filsafat pendidikan menjadi dasar yang menjadi tumpuan suatu sistem pendidikan. Filsafat pendidikan menjadi pedoman bagi usaha-usaha perbaikan, meningkatkan kemajuan dan sebagai dasar yang kokoh bagi tegaknya sistem pendidikan.

Salah satu aliran dalam filsafat adalah eksistensialisme, aliran yang fokus pada pengalaman-pengalaman individual. Eksistensialisme memberi individu suatu jalan berpikir mengenai kehidupan, apa maknanya bagi saya, apa yang benar untuk saya. Pada umumnya eksistensialisme menekankan creative choice (pilihan kreatif), subjectivity (subyektivitas) pengalaman manusia, dan tindakan kongkret (real action) dari keberadaan manusia atas setiap skema rasional untuk hakikat manusia atau realitas. Eksistensialisme mempunyai beberapa pemikiran dan tawaran tentang dunia pendidikan.

\section{B. Filosofi Eksistensialis}

Eksistensialisme merupakan ajaran filsafat yang melihat segala gejala berpangkal pada keberadaan (eksistensi). Eksistensi merupakan salah satu cara manusia berada di dunia. Yangmana cara wujudnya manusia berbeda dengan cara wujudnya benda-benda materi. Dimana keberadaan benda-benda materi berdasarkan ketidaksadaran akan dirinya sendiri, dan juga tidak ada komunikasi antara satu dengan yang lainnya. Namun manusia 
berbeda dengan materi, manusia berada bersama dengan manusia lainnya sama sederajat. Benda-benda materi akan bermakna karena manusia.

Jadi eksistensialisme lahir, karena ingin menempatkan kembali diri manusia pada tempat yang sebenarnya. Manusia sebagai subjek sekaligus sebagai objek. Manusia tidak sama dengan materi, manusia tidak hanya akal dan manusia memerlukan kebahagiaan, ketenangan dan kedamaian.

Eksistensialisme berasal dari pemikiran Soren Kierkegaard (Denmark, 1813-1855). Tokoh-tokoh lainnya yang juga berkontribusi pada eksistensialime antara lain: Martin Buber, Martin Heidegger, Jean Paul Sartre, Gabril Marcel, Karl Jasper, Paul Tillich, dan lain sebagainya. Inti masalah yang menjadi pemikiran eksistensialisme adalah sekitar: (1) apa kehidupan manusia? (2) Apa pemecahan yang konkret terhadap persoalan makna "eksis" (berada) dari manusia?.

Kata ekstensi berasal dari dua kata yaitu; eks (keluar) dan sistensi (diturunkan dari kata kerja sisto bahasa Latin, yang berartinya berdiri atau menempatkan). Justru itu, kata eksistensi diartikan sebagai manusia yang berdiri sebagai diri sendiri dengan keluar dari dirinya. Manusia memiliki kesadaran bahwa dirinya ada. Manusia dapat meragukan segala sesuatu, akan tetapi yang pasti adalah dirinya ada, dan dirinya itu disebut aku. Segala sesuatu di sekitarnya dihubungkan dengan dirinya (handphoneku, komputerku, rumahku, dsbnya). Di dunia, manusia menentukan keadaannya (keberadaannya) dengan perbuatanperbuatannya. Ia mengalami dirinya sebagai pribadi. Ia menemukan pribadinya dengan seolah-olah keluar dari dirinya sendiri dan menyibukkan diri dengan apa yang di luar dirinya. Ia memanfaatkan benda-benda yang ada di sekitarnya. Dengan kesibukannya itulah ia menemukan dirinya sendiri. Ia berdiri sebagai diri sendiri dengan keluar dari dirinya dan sibuk dengan dunia luarnya. Demikianlah manusia bereksistensi. Bereksistensi seperti ini disebut dasein, dari kata $d a$ (di sana) dan sein (berada), sehingga kata ini berarti, berada di sana yaitu di tempat. Manusia senantiasa menempatkan diri di tengah-tengah dunia sekitarnya, sehingga ia terlibat dalam alam sekitarnya dan bersatu dengannya. Sekalipun demikian, manusia tidak sama dengan dunia sekitarnya, tidak sama dengan benda-benda, sebab manusia sadar akan keberadaannya.

Beberapa ahli teori telah memperluas filsafat eksistensialis ke filsafat pendidikan dengan menguraikan implikasi pendidikan pada aliran eksistensialis, seperti Harold Soderquist, Van cleve Morris, dan George Kneller. Kneller telah menunjukkan bahwa 
aliran eksistensialis mencakup beberapa pandangan yang berbeda atau tindakan berfilsafat yang menembus berbagai filosofi, yang juga bukan termasuk dalam filsafat sistematik. Eksistensialisme merupakan suatu cara melihat dan berfikir tentang kehidupan di dunia sehingga prioritas diberikan kepada individualisme dan subjektifitas.

Eksistensialis menerima pernyataan bahwa manusia hidup di suatu dunia yang ada, sebagai suatu fakta kehidupan yang tidak menyenangkan. Kontribusi eksistentialis adalah mencari filosofi individual tentang keteguhan manusia yang perduli terhadap kematian, hidup, cinta, dan makna. Setiap manusia dilahirkan, hidup, memilih jalannya dan menetapkan makna keberadaannya.

Beberapa penilaian pokok dalam penilaian filosofi eksistensialis adalah: (1) keberadaan/eksistensi manusia diberikan begitu saja sebagai kondisi pengalaman tertentu, (2) definisi diri atau keaslian individu ditegaskan dengan membuat beberapa pilihan yang menghasilkan suatu kehidupan yang penuh dengan makna, (3) tugas pendidikan yang utama adalah merangsang setiap manusia agar tersadar bahwa dia sendirilah yang memiliki tanggung jawab untuk menciptakan makna dan definisi dirinya sendiri.

\section{Sejarah Munculnya Filsafat Eksistensialisme.}

Eksistensialisme muncul didorong oleh situasi dunia saat itu. Keadaan dunia khususnya Eropa Barat tidak menentu. Rasa takut berkecamuk, terutama terhadap ancaman perang. Tingkah laku manusia telah menimbulkan krisis. Kebencian merajalela. Agama di Eropa dianggap tidak mampu memberikan makna dalam kehidupan. Manusia menjadi sosok gelisah yang eksistensinya terancam oleh perbuatannya (ulahnya) sendiri. Oleh karenanya manusia benar-benar mengalami krisis. Kondisi demikian, membuat filosof melihat pada dirinya sendiri. Ia berharap suatu pegangan yang dapat menyelamatkan, membawa keluar dari krisis. Sehingga tampil eksistensialisme yang memposisikan manusia sebagai subjek sekaligus objek.

Aliran eksistensialis muncul pada abad ke 19 bertepatan dengan melemahnya aliran optimisme positivis. Semenjak perang dunia, terdapat beberapa bukti tentang malaise (lemas, tidak nyaman) di dunia barat. Beberapa pendapat muncul mengenai suatu trend dalam sekelompok masyarakat yang bekerja tetapi justru mengurangi kepribadian bahkan merendahkan individu. Muncullah sikap krisis sebagai wujud usaha manusia dalam menghadapi dampak dari produksi dan konsumsi masal yang diakibatkan oleh revolusi industri dan teknologi. 
Revolusi industri memperkenalkan mekanisme yang inovatif dalam mendukung produksi, penawaran dan permintaan yang efisien sehingga dapat mengatasi kelangkaan barang dan jasa secara kuantitatif, tetapi kelemahannya adalah melumpuhkan pengaruh pada aspek kualitatif atau manusia di kehidupan. Yang pada akhirnya, makna individu sebagai seseorang semakin minim.

Teknologi yang kompleks memiliki peran yang mengarahkan pada standarisasi produksi. Sehingga setiap orang disamakan sebagai manusia tersandarisasi/dapat diukur yang kebutuhannya, keinginannya, dan harapannya juga dapat diukur. Fitur-fitur perusahaan dan standarisasi masyarakat massa tidak terbatas pada bidang ekonomi, politik, dan kehidupan sosial saja, tetapi juga telah diperluas di bidang pendidikan. Sekolahsekolah menyerupai sebuah pabrik pendidikan karena dilakukan di gedung besar agar dapat mengedukasi banyak siswa dan bertujuan menghasilkan produk yang terstandarisasi. Metode pembelajaran dirancang agar proses belajar lebih efisien sehingga dapat mendidik siswa dalam jumlah yang banyak. Berbagai aspek teknologi pendidikan seperti mesin pengajar, pembelajaran yang disiarkan di TV, paket pengajaran multimedia, dan tes standar telah diperkenalkan untuk membuat pembelajaran lebih efisien.

Situasi pendidikan pada masa ini memiliki ciri yaitu ukuran kelas besar, birokrasi yang impersonal, dan sedikit interaksi antara guru dan siswa. Disinilah aliran eksistensialisme muncul sebagai upaya dalam mengurangi impersonalisasi yang mempengaruhi sekolah pada abad ke 20 dan menekankan kembali hubungan "I-THOU" atau "aku-kamu" antara guru dan siswa. Eksistensialis memiliki komitmen untuk membentuk kembali situasi manusia agar memiliki kepribadian manusia yang paling tinggi, paling bebas, dan paling asli. ${ }^{1}$

Eksistensialis melihat kehidupan sangat bervariatif, kompleks, dan sulit diprediksi dalam kategori filosofi yang tersusun rapi. Eksistensialisme menolak sistem metafisik arsitektonis yang berkaitan dengan filosofi tradisional seperti idealisme dan realisme, serta menolak kebergantungan peneliti pada metode ilmiah. Eksistensialisme menyimpang dari sistem filsafat yang memandang dunia dengan membuat kategorisasi pengalaman manusia berdasarkan konsep realitas sebelumnya. Eksistensialis menyangkal universal, absolut, dan kategori.

${ }^{1}$ Gerald Lee Gutek, 1974, Philosophical Alternatives in Education, (Columbus Ohio: Charles E. Merrill Publishing Company), p.195-197 
Eksistensialis keberatan pada premis-premis yang dinyatakan oleh Aristotelian. Misalnya realis alam aristotelian menegaskan keberadaan suatu tatanan objektif realitas tidak bergantung pada rencana dan tujuan manusia. Manusia sebagai bagian dari realitas tersebut dan sebagai makhluk rasional memiliki tugas tertentu didalamnya yaitu bertindak atau berperilaku rasionalis. Hal ini berarti bahwa akal dianggap sebagai komponen utama dalam definisi manusia dan akal juga dianggap sebagai dasar dan penentu dari sifat manusia. Akibatnya, manusia tidak dapat benar-benar memilih alasan sebagai nilai.

Eksistensialis juga menolak filosofi pendidikan eksperimental Dewey yang menekankan pada metode ilmiah dan asosiasi manusia. Hal ini dikarenakan, individu memiliki kemampuan membentuk kebenaran yang tentatif melalui prosedur sains empiris. Meskipun Dewey percaya bahwa individu memliki memperoleh kebebasan melalui interaksi kelompok, beberapa eksistensialis beranggapan bahwa ada penyeragaman individu untuk memiliki pikiran yang sama di bawah kehendak kelompok. Artinya, individu dipaksa untuk mematuhi keputusan yang disepakati kelompok.

Reaksi Anti Ilmiah yang ada pada Era modern ditandai dengan penerapan sains/metode ilmiah/objektifitas untuk mencapai kebenaran dan memecahkan masalah. Adanya metode ilmiah dapat meminimalkan subjektifitas dan nilai. (keinginan pribadi, preferensi dan prasangka tidak diizinkan). Adanya Kuantifikasi pengalaman manusia, dan tidak dengan kualitasnya.

Premis dasar eksistensialisme adalah "eksistensi mendahului esensi" yang menekankan keunggulan subjektivitas manusia. Manusia ditempatkan pada posisi sebagai "pembuat esensinya" yaitu manusia mendefinisikan dirinya sendiri. Hal ini dapat dilakukan dengan membuat pilihan individu, pribadi, dan subjektif. Inti dasar filsafat eksistensialis adalah menggambarkan usaha manusia untuk mendifinisikan dirinya melalui pilihan. Selain itu, tujuan manusia tidak ditemukan dalam struktur metafisis, teologis, atau sosiologis alam semessta. Manusia bertanggungjawab untuk membuat nilainya sendiri. Hal ini menunjukkan manusia merupakan individu yang unik.

Masalah filosofi dasar pada eksistesialis adalah menilai dan memilih. Nilai-nilai tersbut muncul sebagai hasil dari pilihan pribadi dan Ia menciptakan dan membingkai nilai-nilainya sendiri. Usaha pencarian kehidupan dan pendidikan eksistensialis diperuntukkan pada manusia sejati yang bebas dan sadar akan kebebasannya. Sadar bahwa setiap pilihan yang dibuat adalah tindakan menghasilkan nilai pribadi. Dia juga menyadari 
bahwa definisi diri tidak pernah ditentukan oleh siapapun dan apapun kecuali dirinya sendiri. Masalah dasar eksistensialis juga dikarenakan oleh hubungan diri individu dengan orang dan lembaga lain. Morris kemudian memperkenalkan arti persahabatan sebagai suatu pertemuan antara orang-orang dan tidak memperlakukan sujektivitasnya sebagai fungsi atau objek. Ia menekankan pada hubungan "AKU-KAMU"

\section{Pemikiran Pendidikan Eksistensialisme.}

\section{Pemaksaan Pendidikan Modern}

Tradisi pendidikan di Amerika didasarkan pada konsep sekolah umum Horace Mann dan Henry Barnard yang memahami sekolah sebagai instrumen untuk menggabungkan berbagai kelompok ras, sosial, etnis, agama, dan ekonomi menjadi identitas nasional yang sama. Peran dari bahasa dan kurikulum pada sekolah umum adalah sarana untuk mencapai intgrasi nasional dengan memaksa individualitas dan keragaman. Pendidikan pada masyarakat cenderung mirip dengan perusahaan besar yang mengurangi hubungan belajar-mengajar/siswa-guru. Selain itu, pendidikan formal dapat menghalangi keaslian pribadi karena adanya kuantifikasi yang diarahkan pada standarisasi.

Pada pendidikan Amerika Kontemporer didominasi dengan teori psikologi pendidikan yang menekankan pada pengakuan dan penyesuaian sosial, sehingga aktivitas belajar berpusat pada kelompok. Tujuan pendidikan yang disosialisasikan adalah belajar berhubungan atau berinteraksi dengan yang lain, entah itu dalam suatu kelompok, tim, maupun komite pembelajaran. Menurut teori-teori pendidikan yang berpusat pada kelompok, individu menjadi lebih efektif dan efisien jika ia menentukan dan berpartisipasi dalam kelompok.

Sedangkan pendidik eksistensialis mengkritisi aktifitas belajar yang terlalu menekankan pada kelompok. Hal ini dikarenakan ada beberapa individu yang masih kesepian dan cemas. Situasi pembelajaran yang berpusat pada kelompok memungkinkan individu untuk mengorbankan keaslian pribadi karena dipaksa harus berpikiran sama sesuai kesepakatan. Jika seseorang memiliki kebebasan untuk memilih bergabung dan berpartisipasi dalam suatu kelompok dan tidak ada pengaturan bagaimana situasi belajar harus terjadi, maka masih dimungkinkan adanya keaslian pribadi. ${ }^{2}$

${ }^{2}$ Gerald Lee Gutek, 1974, Philosophical Alternatives in Education, (Columbus Ohio: Charles E. Merrill Publishing Company), p.200-201 
2. Pedagogi Eksistensialis

Morris menegaskan bahwa pendidikan harus dapat menumbuhkan "intensitas kesadaran” siswa. Ia juga menyatakan bahwa “ jika pendidikan harus sungguh-sungguh manusia, maka harus dapat membangkitkan kesadaran dalam kesadaran pembelajar eksistensialis yang dimiliki sebagai kehadiran subjektivitas tunggal di dunia". Artinya, siswa harus mengakui bahwa Ia adalah individu yang bebas dan kreatif dalam memilih. Siswa juga sadar akan tanggung jawabnya untuk menentukan kehidupan yang akan dijalani sendiri dan menciptakan definisi dirinya sendiri. Pendidikan seyogyanya menekankan refleksi personal yang mendalam terhadap komitmen dan pilihan sendiri. Manusia adalah pencipta esensi dirinya. ${ }^{3}$ Siswa dilihat sebagai individu, dan belajar seyogyanya disesuaikan dengan kecepatan siswa dan siswa mengarahkan belajar untuk kepentingan dirinya sendiri. ${ }^{4}$

Eksistensialisme erat kaitannya dengan pendidikan, karena keduanya bersinggungan satu dengan yang lainnya pada masalah-masalah yang sama, yaitu manusia, hidup, hubungan antar manusia, hakikat kepribadian, dan kebebasan (kemerdekaan). Pusat pembicaraan eksistensialisme adalah keberadaan manusia, sedangkan pendidikan hanya dilakukan oleh manusia. ${ }^{5}$

Dua periode dalam pendidikan eksistensialisme adalah: (a) periode pra eksistensialis, (b) periode momen eksistensialis. Periode pra eksistensialis adalah masa kanak-kanak (sebelum pubertas), anak tidak menyadari kondisi manusia, anak belum sadar akan identitas dan takdir pribadi, berada pada waktu pendidikan dasar, keterampilan yang dikembangkan adalah membaca, menulis, aritmatik dan komunikasi, keterampilan fisik, rekreasi, sosial, dan keterampilan pemecahan masalah.

Periode momen eksistensialis adalah (a) individu sadar akan kehadirannya sebagai diri di dunia, (b) memiliki wawasan akan kesadarannya sendiri dan sadar akan kehadiran serta bentuk tanggung jawabnya di dunia, (c) Individu mengalami momen eksistensialis yang bervariasi, tapi kebanyakan orang mengalami saat pubertas, (d) dimulai pada tahun-

\footnotetext{
${ }^{3}$ Gerald Lee Gutek, 1974, Philosophical Alternatives in Education, (Columbus Ohio: Charles E. Merrill Publishing Company), p.201-202

${ }^{4}$ A. Chaedar Al Wasilah, 2015, Pengantar Filsafat Bahasa dan Pendidikan, (Bandung: Remaja Rosda Karya), p.107

${ }^{5}$ Uyoh Sadulloh, 2018, Pengantar Filsafat Pendidikan, (Bandung: Alfabeta), 137
} 
tahun sekolah menengah pertama dan terus berlanjut melalui sekolah menengah atas dan perguruan tinggi. ${ }^{6}$

Dorongan dari pendidikan seperti itu adalah untuk membangkitkan dan meningkatkan kesadaran diri. Itu akan diakhiri dengan pengalaman afektif, dengan elemen-elemen pengalaman yang subjektif dan pribadi yang akan mendorong keterlibatan dalam situasi yang kondusif bagi pengetahuan bahwa seseorang terlibat dalam pertanyaan baik atau buruk dan benar atau salah.

3. Epistemologi Eksistensialis

Epistomologi eksistensialis menganggap bahwa individu bertanggung jawab akan pengetahuannya sendiri. Sumber pengetahuan yang utama adalah pengalaman pribadi. ${ }^{7}$ Epistomologi eksistensialis muncul dari pengalaman dan pengetahuan manusia yang bersifat subyektif, pribadi, rasional, dan irasional. Validitas pengetahuan ditentukan oleh nilainya dan artinya bagi individu tertentu. Para eksistensialis lebih senang menyelidiki tentang keindahan, moral, dan emosional manusia, serta faktor-faktor kognitifnya. ${ }^{8}$

Morris menggambarkan epistomologi eksistensialis sebagai "apropriasi". Apropriasi adalah sebuah pilihan, pengambilan, dan adopsi pribadi tentang sesuatu yang tersedia untuk semua. Setiap kebenaran pertama-tama harus ditangkap dan disesuaikan oleh seorang pelajar.

Konsep epistemologi aproriasi dapat diperjelas dengan menggunakan contoh dari kelas sejarah. Misalkan, seorang guru sejarah membuat pernyataan faktual sederhana bahwa partai republik menominasikan Abraham Lincoln untuk Presiden pada tahun 1860. Pernyataan semacam itu didasarkan pada data yang ada dalam catatan sejarah, yang mencakup sumber primer dan sekunder. Ada interpretasi historis tentang dampak pencalonan Lincoln terhadap perjalanan sejarah Amerika. Beberapa sejarawan telah menuduh bahwa pencalonan Lincoln dan pemilihan berikutnya menyebabkan negaranegara selatan untuk memisahkan diri dari Union, menyebabkan pembunuhan Lincoln. Namun demikian, adalah mungkin untuk menyatakan bahwa suatu peristiwa terjadi, bahwa

\footnotetext{
${ }^{6}$ Gerald Lee Gutek, 1974, Philosophical Alternatives in Education, (Columbus Ohio: Charles E. Merrill Publishing Company), p.203

${ }^{7}$ J.A. Akinpelu, 1988, An Introduction to Philosophy of Education, (London and Basingstoke: Mc Millan Publisher, Ltd.), p.157

${ }^{8}$ Gerald Lee Gutek, 1974, Philosophical Alternatives in Education, (Columbus Ohio: Charles E. Merrill Publishing Company), p.203
} 
Lincoln dinominasikan untuk Presiden pada tahun 1860. Tampaknya ada materi pelajaran yang objektif dan eksternal baik bagi guru maupun siswa. Tentu saja baik guru maupun siswa tidak bertanggung jawab atas pencalonan Lincoln.

Aspek penting dari fakta pencalonan Lincoln bahwa siswa ingin memberikan makna kepada peristiwa bersejarah ini dengan menyesuaikannya ke dalam kesadarannya sendiri. Setiap siswa menciptakan dan bertanggung jawab secara pribadi untuk memberi makna pada acara tersebut. Mungkin bermanfaat untuk mempertimbangkan beberapa kemungkinan untuk makna yang mungkin dimiliki oleh peristiwa sejarah yang begitu sederhana bagi siswa. Pencalonan Lincoln mungkin dipandang sebagai kemenangan pribadi bagi seorang pria yang mampu membuat diri sendiri mampu mengatasi kepemimpinan para pemuda perbatasannya untuk menjadi pemimpin bangsa. Sebaliknya, itu mungkin dilihat sebagai hasil dari kepraktisan Lincoln dalam berurusan dengan masalah perbudakan Negro dalam kampanye pemilihannya sebelumnya untuk Senator dari illionis. dalam kasus peristiwa historis yang demikian, masa lalu mengambil makna yang ditentukan oleh pilihan dan proyek pelajar saat ini.

Pengetahuan yang diberikan di sekolah bukan sebagai alat untuk memperoleh pekerjaan atau karir anak, melainkan untuk dapat dijadikan alat perkembangan dan alat pemenuhan diri. Pelajaran di sekolah akan dijadikan alat untuk merealisasikan diri, bukan merupakan suatu disiplin yang kaku dimana anak harus patuh dan tunduk terhadap isi pelajaran tersebut. Biarkanlah pribadi anak berkembang untuk menemukan kebenarankebanaran dalam kebenaran. ${ }^{9}$

4. Kurikulum Eksistensialis

Mata pelajaran sekolah seperti sejarah, sastra, bahasa, matematika dan sains hanya berperan sebagai kerangka ilmu dan sumber informasi yang digunakan untuk realisasi subjektivitas. Fase pembelajaran yang krusial tidak ditemukan dalam struktur pengetahuan atau dalam organisasi disiplin ilmu yang dipelajari, tetapi lebih pada apropriasi siswa terhadap subjek - kesediaannya untuk memilih dan memberi makna pada subjek tersebut. Tidak ada satu mata pelajaran tertentu yang lebih penting daripada yang lainnya. Mata pelajaran merupakan materi dimana individu akan dapat menemukan dirinya dan kesadaran akan dunianya.

\footnotetext{
${ }^{9}$ Uyoh Sadulloh, 2018, Pengantar Filsafat Pendidikan, (Bandung: Alfabeta), 136
} 
Kurikulum ideal adalah kurikulum yang memberi siswa kebebasan individual yang luas dan mensyaratkan mereka untuk mengajukan pertanyaan-pertanyaan, melaksanakan pencarian-pencarian mereka sendiri, dan menarik kesimpulan mereka sendiri. Kurikulum eksistensialisme memberikan perhatian besar pada kajian humaniora dan seni. Hal itu disebabkan oleh kedua materi tersebut diperlukan agar individu (manusia) dapat mengadakan instropeksi dan mengenalkan gambaran (eksistensi) dirinya. Pelajar-pelajar harus dimotivasi untuk melakukan kegiatan yang dapat mengembangkan keterampilan yang mereka dibutuhkan, dan juga mendapatkan pengetahuan yang dibutuhkan (diharapkan). ${ }^{10}$

Kurikulum eksistensialis menempatkan siswa sebagai aktor yang memberikan makna pada subjek yang ia apropriasi, yaitu dengan memasukkannya kedalam dirinya sendiri dan menafsirkannya sesuai dengan proyeknya sendiri. Seperti yang Morris katakan, 'pengalaman apa pun di sekolah yang paling mungkin membangkitkan cara pribadi seseorang dalam memandang kehidupan akan diangkat ke posisi pertama dalam hal apa pun, mungkin suatu hari nanti yang akan disebut sekolah eksistensialis.

Kurikulum sebenarnya digunakan sebagai wahana interpretasi, yang mencakup unsur kognitif dan normatif. Kerangka pengetahuan faktual, deskriptif, dan ilmiah dari dimensi kognitif mewakili pemberian tatanan fenomenologis. Dimensi normatif atau sikap terdiri dari bidang-bidang kurikuler terutama etis. Studi humanistik seperti sejarah, seni, sastra, filsafat, dan agama merupakan studi yang kaya akan sumber nilai-nilai etika.

Misalnya, pada mata pelajaran seni seperti musik, drama, tari, menulis kreatif, melukis, dan film dirancang untuk menumbuhkan pengalaman estetika. Tujuan pendidikan seni menurut eksistensialis bukan untuk meniru gaya seniman yang dipilih, meskipun ini dipelajari, tetapi lebih untuk merangsang ekspresi estetika. Peran guru disini adalah membangkitkan dan menstimulasi rasa dan keinginan pembelajar untuk ekspresi estetika. Guru menyediakan berbagai media kreatif sehingga pelajar akan memiliki bahan mentah untuk membuat objek seninya sendiri yang berasal dari pusat pengalamannya sendiri. ${ }^{11}$

5. Proses Pembelajaran Eksistensialis

${ }^{10}$ Uyoh Sadulloh, 2018, Pengantar Filsafat Pendidikan, (Bandung: Alfabeta), 138

${ }^{11}$ Gerald Lee Gutek, 1974, Philosophical Alternatives in Education, (Columbus Ohio: Charles E. Merrill Publishing Company), p.204-205 
Metode pendidikan yang dipilih mengacu pada hubungan pribadi antara guru dan siswa "AKU-KAMU”. Metode pembelajaran yang tepat adalah dialog. Dialog merupakan percakapan (komunikasi) antar pribadi, dimana setiap pribadi merupakan subjek bagi pribadi lainnya, dan merupakan suatu percakapan antara Aku dan Kamu. Adapun lawan dari dialog merupakan paksaan, dimana seseorang (manusia) memaksakan kemauannya (kehendaknya) kepada orang lain sebagai objek.

Selain dialog metode yang baik menurut eksistensialis adalah bermain peran dan drama, selama siswa dapat mengimajinasikan dirinya sebagai peran yang ia jalankan dalam permainan tersebut, dan itulah yang disebut dengan pengalaman yang mewakili situasi tersebut. ${ }^{12}$

Pandangan eksistensialis tentang guru adalah hendaknya guru tidak boleh disamakan dengan seorang instruktur. Jika guru disamakan dengan seorang instruktur, maka ia hanya merupakan perantara yang sederhana antara materi pelajaran dengan siswa. Seandainya guru dianggap seorang struktur, ia akan turun martabatnya, sehingga ia hanya dianggap sebagai alat untuk mentrasfer ilmu pengetahuan, dan siswa akan menjadi hasil dari transfer tersebut. Pengetahuan akan menguasai manusia, sehingga manusia akan menjadi alat dan produk dari pengetahuan tersebut.

Dalam proses pembelajaran, pengetahuan tidak dilimpahkan, melainkan ditawarkan. Untuk menjadikan hubungan antara guru dengan siswa sebagai suatu dialog, maka pengetahuan yang akan diberikan kepada siswa harus menjadi bagian dari pengalaman pribadi guru itu sendiri, sehingga guru akan berjumpa dengan siswa sebagai pertemuan antara pribadi dengan pribadi. Pengetahuan yang ditawarkan guru tidak merupakan sesuatu yang diberikan kepada siswa yang tidak dikuasainya, melainkan merupakan suatu aspek yang telah menjadi miliknya sendiri.

Guru eksistensialis tidak mengetahui jawaban dari pertanyaan-pertanyaan yang diajukan. Memang, jenis pertanyaan terbaik adalah yang dapat dijawab hanya oleh siswa itu sendiri. Pertanyaan ini diajukan agar siswa menjadi sadar akan kondisi hidupnya, sehingga jawaban muncul sesuai subjektivitas individu itu sendiri. Guru bertugas untuk menstimulasi "intesitas kesadaran" siswa dengan mendorong pencarian kebenaran pribadi melalui pengajuan pertanyaan tentang makna kehidupan. Penciptaan "intensitas kesadaran"

\section{J.A. Akinpelu, 1988, An Introduction to Philosophy of Education, (London and} Basingstoke: Mc Millan Publisher, Ltd.), p.160 
adalah tanggung jawab pembelajar sendiri sama seperti tanggung jawab guru. Kesadaran seperti itu melibatkan rasa percaya yang terlibat dalam dimensi etis dan estetika keberadaan. ${ }^{13}$

Eksistensialis berpendapat bahwa guru yang terbaik adalah rumah dan orangtua yang membersamai anak, sebab mereka bisa menerima anak secara penuh dan juga bisa menerima kelemahan-kelemahan dirinya, anak-anak tetap disayangi bersama dengan saudara yang lainnya. Guru hendaknya bisa memposisikan diri sebagai orangtua dalam hal menerima keunikan individu yang mempunyai kemampuan yang berbeda-beda. Siswa adalah individu yang berkembang dengan segala potensi yang dimilikinya. Tugas guru adalah membantu siswa merealisasikan potensinya, menemukan dirinya, dan bagaimana bisa mencapai hal tersebut. Guru harus menjadi konselor dan pembimbing. Tujuan akhir guru adalah membuat siswa independen dan mandiri, mampu membuat keputusan sendiri dan cukup berani untuk menindakinya dan menerima tanggung jawab penuh atas keputusan tersebut. Guru hendaknya mengetahuia satu persatu murid yang diajarnya, misal dalam kelas ada 35 siswa, maka guru harus hafal nama-namanya dan mengetahui keunikan masing-masing siswa. Guru tidak boleh melihat siswa dari kemampuan akademik siswa saja. $^{14}$

Guru harus berhati-hati dalam penilaian dan evaluasinya karena beberapa penilaian diperlukan baginya untuk menentukan kualitas dan kuantitas pembelajaran yang sudah dilaksanakan. Penilaian yang ceroboh dapat menghancurkan individu anak dengan cara dia gegabah. Kata-kata emotif tertentu telah menjadi umum dalam perbendaharaan kata guru untuk menggambarkan murid bodoh, berprestasi rendah, tidak perhatian, berprestasi kurang, orang dungu, dan sebagainya. Masing-masing dari kata-kata itu membangkitkan jumlah asosiasi yang tidak menguntungkan lainnya ketika digunakan untuk mencari kelemahan siswa yang dirujuk berdasarkan satu aspek saja. Jika ia tidak unggul dalam akademik, ia mungkin pandai dalam bidang kreatif, fisik, atau artistik lainnya. Kegagalan sistem pendidikan untuk memberikan peluang bagi kemungkinan terbuka dan kegagalan

${ }^{13}$ Gerald Lee Gutek, 1974, Philosophical Alternatives in Education, (Columbus Ohio:

Charles E. Merrill Publishing Company), p.206

${ }^{14}$ J.A. Akinpelu, 1988, An Introduction to Philosophy of Education, (London and Basingstoke: Mc Millan Publisher, Ltd.), p.161 
guru untuk menemukan titik kuat siswa, kemudian siswa yang disalahkan. Guru harusnya bisa mengolah sikap optimis khususnya terkait dengan opini terhadap siswa.

Konsep penting eksistensialis terkait dengan sikap guru adalah hendaknya guru mengizinkan kebebasan berpendapat dan berdiskusi dalam kelas, karena mengetahui sesuatu menurut pandangannya sendiri, yang didasarkan pada pengalaman yang unggul dan pengetahuan yang lebih luas akan membawa lebih banyak beban bagi guru. Siswa bisa mencoba berbagai kebebasan berekspresi, guru yang bertugas untuk membuat atmosfer kelas yang toleran dan tanpa rasa takut untuk menyampaikan pendapat. Pada akhirnya, guru harus terlibat secara langsung dalam kehidupan siswa untuk mendiskusikan kegembiraan dan kesedihan mereka, serta harapan dan aspirasi mereka. Guru mencintai dan menghormati siswa sebagai individu. Guru harus berkomitmen untuk membuat siswa sukses dalam menemukan dirinya, merealisasikan potensinya, menjadi pribadi yang mandiri dan otonom. Guru harus menunjukkan perhatian dan keseriusannya, serta mempunyai rasa tanggung jawab yang besar bahwa kenyataannya mendidik itu membimbing kehidupan generasi yang akan datang dan menentukan nasib orang lain. ${ }^{15}$

\section{E. KESIMPULAN}

Berbeda dengan filosofi tradisional, eksistensialisme berusaha membebaskan manusia dari belenggu alam semesta yang dikategorikan dan disistematisasi. Eksistensialisme menggambarkan manusia sebagai makhluk yang ada di dunia, yang memiliki tanggung jawab atas definisi dirinya berdasarkan pada penekanan subjektivitas manusia, kebebasan pribadi, dan tanggung jawab individu. Pencarian keaslian dilakukan dengan kesadaran bahwa dia lah yang membuat nilai-nilainya sendiri dan menciptakan esensinya sendiri tanpa bantuan dari luar.

Fokus dari Pendidikan eksistensialis adalah kebebasan manusia. Dalam upaya menekankan subjektivitas individu, guru eksistensialis harus mampu menumbuhkan rasa kesadaran diri dan tanggung jawab siswa. Untuk pembuatan pilihan pribadi yang signifikan, hanya siswalah yang mampu menghasilkan definisi dirinya. Setiap orang memiliki tanggung jawab untuk pendidikannya sendiri dan tidak bisa dipaksakan oleh guru maupun sistem sekolah.

${ }^{15}$ J.A. Akinpelu, 1988, An Introduction to Philosophy of Education, (London and Basingstoke: Mc Millan Publisher, Ltd.), p.161-162 


\section{DAFTAR PUSTAKA}

Abidin, Jam'ah, 2013, Pengembangan Pendidikan dalam Filsfat Eksistensialisme, AlFikra: Jurnal Ilmiah Keislaman, Vol. 12, No. 2, Juli - Desember.

Akinpelu, J.A, 1988, An Introduction to Philosophy of Education, London and Basingstoke: Mc Millan Publisher, Ltd.

Al Wasilah, A, Chaedar, 2015, Pengantar Filsafat Bahasa dan Pendidikan, Bandung: Remaja Rosda Karya.

Gutek, Gerald Lee, 1974, Philosophical Alternatives in Education, Columbus Ohio: Charles E. Merrill Publishing Company.

Sadulloh, Uyoh, 2018, Pengantar Filsafat Pendidikan, Bandung: Alfabeta 